\title{
Social Feminism and Legal Discourse: 1908-1923
}

\author{
Sybil Lipschultz†
}

\section{INTRODUCTION}

There is a "male standard" in law, Florence Kelley proclaimed through the early 1920's. Kelley, the executive secretary of the National Consumers' League, believed existing legal rules and rhetoric represented only men's interests. If women were subject to these male rules, she reasoned, this equal treatment would yield unequal results. Kelley wanted equality for women, but she was firmly committed to an equality based on women's differences from men, rather than an equality grounded on gender neutrality. She tried to introduce to American law a female standard, one that created new legal rhetoric, concentrating on women's distinct experiences. This equality-through-difference approach was summed up by the phrase "industrial equality," which women who agreed with Kelley used to explain their approach to law and social change."

Historians have dubbed these women "social feminists." They were the women who staffed the many reform organizations that grew between the late nineteenth century and the New Deal. Many had political roots in the settlement houses, where they began to create child- and womancentered reforms that built the foundation for the welfare state. Among their important reforms was protective labor legislation for women. These laws limited the hours women could work, provided a variety of on-thejob health and safety measures for women, and attempted to put a legal floor on the wages a woman could earn. ${ }^{3}$

+ Assistant Professor of History and Women's Studies, University of Miami, Coral Gables, Florida. For insightful criticism and useful responses to various versions of this paper, I would like to thank Eileen Boris, Mary Coombs, Daniel Ernst, Martha Fineman, Linda Gordon, Dirk Hartog, Alice Kessler-Harris, Alex Lichtenstein, Martha Minow, Kathryn Kish Sklar, Susan Ware, Lucie White, Wendy Williams, the participants in the 1988 Feminism and Legal Theory Conference at the University of Wisconsin-Madison, and the editors of the Yale Journal of Law and Feminism.

1. For examples of this kind of rhetoric, see Kelley, The Equal Rights Amendment, N.Y. Evening Sun, Mar. 11, 1924; Nat'l Consumers' League, Why It Should Not Pass: The Blanket Equality Bil.l. Proposed by The National. Woman's Party for State legislatures (1922) [hereinafter NCL, Why It Should Not Pass]; Nat'l League of Women Voters, Specific BilLS fOR SPECIFIC ILLS (1924).

2. See W. O'Neill, everyone was brave at x (1969); J.S. Lemons, The Woman Citizen: Social. Feminism in the 1920s at vii (1973).

3. For an overview of protective labor legislation, see Hill, Protection of Women Workers and the Courts: A Legal Case History, 5 FEMinist Studies 247 (1979). 
Historians tend to cast the social feminists as rather static in their approach to reform, depicting them as women who valued general social reform over feminism and who unquestioningly accepted women's dependency on men. Although it is true that social feminists did not challenge women's dependency until 1920, a longer view of social feminism, presented in this article, reveals that it underwent important changes in the 1920's. In the 1920's, social feminist claims to industrial equality, or legal equality-through-difference for working women, demonstrated a growing egalitarian spirit and a feminist approach to law and women's lives. This feminism was an alternative to the equal rights model, or equality-through-sameness, commonly associated with the National Woman's Party and the standard history of American feminism. The alternative of equality-through-difference is best exemplified by the social feminist campaign for a women's minimum wage based simultaneously on women's value as workers and as domestic caretakers.

The new vision of industrial equality presented some significant problems for social feminists, however. They were committed to legal remedies for women's social and economic ills. To carry out this strategy they needed lawyers, and they joined with some of the leading liberal attorneys of their day. Louis Brandeis, for example, agreed to argue Muller v. Oregon ${ }^{5}$ for the Consumers' League in 1908, and continued to argue women's labor law cases for the League until his Supreme Court appointment in 1916. Felix Frankfurter took Brandeis' place as legal counsel for the League, and became responsible for litigation in Adkins v. Children's Hospital, ${ }^{6}$ the women's minimum wage test case. He and other lawyers close to social feminist groups, such as the Consumers' League, did not share the industrial equality vision. Rather, the lawyers whom social feminists needed to take their case for equality-through-difference to court expressed views about women and equality that were in sharp contrast with social feminism.

Social feminists were saddled with lawyers who basically believed in women's inferiority, and who read proposals for highlighting women's differences as formulae for inequality. These lawyers were generally liberal in their politics, but they were also the emissaries of the received tradition in law, and they transmitted values and ideologies deeply embedded in dominant interpretations of the Constitution. By separating female social feminists from the male lawyerly company they kept, this article shows important differences along gender lines in a group historians have formerly treated as harmonious. ${ }^{\text {? }}$

\footnotetext{
4. See, e.g., W. O'NeILL, supra note 2; J.S. Lemons, supra note 2.

5. 208 U.S. 412 (1908) (women's hours limitation).

6. 261 U.S. 525 (1923)

7. For examples of that view of the reform movement, see generally J. WEINSTEIN, ThE Corporate Ideal in the Liberal State: 1900-1918 (1968); R. Lubove, The Struggle for Social
} 
Important changes in social feminism can be viewed through the window of two major Supreme Court cases. Muller $v$. Oregon, the women's hours limitation case of 1908 , is the quintessential example of the social feminists' early acceptance of dependency. Muller won hours limitation for women on the basis of women's relative physical weakness and other claimed biological differences as well as their lack of suffrage rights. Social feminism was transformed, however, by 1923, and these changes were evident in the less successful Adkins $v$. Children's Hospital. This postsuffrage case denied women the right to a minimum wage because they had purportedly won "equality" with men when the Nineteenth Amendment was ratified. Taking their cue from the suffrage victory, social feminists argued that women were entitled to a state-imposed floor on their wages because of economic differences-because they earned less than men. Furthermore, they argued that women's differences from men demanded legal attention, especially the social differences of childrearing and domestic caretaking. During the 1920 's, the social feminist stress on social and economic differences, and an accompanying refusal to discuss biological differences, marked an important change in the movement. Encouraged by legal victories, social feminists were pushing beyond their own prior limitations.

It was litigation strategy, however, that eventually limited social feminism. Forced to put their ideal of industrial equality into legal discourse, social feminists faced a legal ideology strictly at odds with their perspective. The cruel irony of working with lawyers who did not share their views on women cut deeply into social feminist attempts to enact industrial equality. Failure to prevail in Adkins, moreover, curtailed the social feminists' sense of legal possibilities, much to the detriment of their movement. Equality-through-difference, or industrial equality, was not an idea whose time had arrived. Instead legal discourse shaped and reshaped this idea until it was no longer recognizable. At the same time, the litigation process reshaped the social feminist movement until adherents finally gave up on industrial equality.

This article brings to light the social feminist political vision of the 1920 's, equality-through-difference, which they called "industrial equality." It argues that industrial equality shaped advocacy of protective labor legislation during the twenties, separating litigation in that decade from

Security: 1900-1935 (1986); G. Kolko, The Triumph of Conservatism (1963). Studies of men's reform efforts tend to link their activities to preservation of capitalism. These studies, however, do not address the role of women in reform and the different manner in which social feminists addressed reform issues for women and children. Unraveling women's approaches to the state may reveal a social feminism less committed to capitalism and more devoted to a gender specific politics of law. Furthermore, studies of gender are bringing to new light alternatives to the social control thesis of American reform. See Gordon, What Does Welfare Regulate?, 55 Soc. RES. 609 (1988), for an important critique of the social control thesis and a response to F. PIven \& R. Cloward, Regulating the Poor: The Functions of Public Welfare (1971). 
the earlier period. This article further shows how those changes put social feminists at variance with the liberal male lawyers who took their labor law cases to court. This was a particularly important issue with Felix Frankfurter, who argued the women's minimum wage test case before the U.S. Supreme Court. In that case, Adkins v. Children's Hospital, social feminist Molly Dewson wrote a brief which attempted to articulate industrial equality within the confines of existing legal rules and concepts. Understanding the Adkins brief in the context of industrial equality promotes a new explanation of social feminism and the law in the 1920's. Thus, this article concludes that social feminists were hampered by a friendly lawyer who did not understand the feminist dimensions of the case, and a hostile Court which insisted on a vision of equality based on sameness. As a result, the social feminist case for industrial equality was severely limited by legal institutions and legal discourse of the 1920's.

\section{From Dependency to Industrial EQuality: Muller and Adkins}

In 1920, suffrage, that apparent panacea, had been won, and it left social feminists with a new sense of power and legitimacy. They were confident a new age of feminine values was dawning, and women would now humanize the cruel environment they had long wanted to reform. Most significantly, these social feminists were imbued with a feeling of success, which encouraged them to push ahead in wider social reforms. Industrial justice for women through labor laws held a prominent place on that agenda. In 1920 there was no issue more important in completing the labor law campaign than the women's minimum wage.

The issue of minimum wages for women in the 1920's is part of a larger history of "protective" labor laws. Today these laws are often associated with restrictions on women's employment which now constitute sex-discrimination. It is, therefore, sometimes difficult to understand early twentieth-century perspectives on these laws. Social feminists who supported these laws in the twenties called them "women's labor laws," consciously rejecting the idiom "protective labor laws," which they had used in the previous decade. There is significance to this shift in rhetoric. Social feminists no longer thought of themselves as "paternalistically" (maternalistically?) taking care of other women; instead, they saw this as positive action for women. However, social feminists' intent notwithstanding, separate women's labor laws, as constructed in the early twentieth century, did result in restriction and contributed to women's secondary and inferior position in the labor force. ${ }^{8}$

8. Boris, Looking at Women's Historians Looking At "Difference," 3 WIS. Women's L.J. 213, 223 (1987), explains that whatever social feminist intent may have been, it could not override "constraints of the larger culture," and it reinforced a sex-segregated workplace. 
Although the women's minimum wage was a social feminist issue, as were other women's labor issues of the early twentieth century, it was distinct from other women's labor laws. In the Progressive period and during the New Deal, arguments for women's labor laws stressed "sacred motherhood" and the need to protect women from harm for the sake of the future generation. This rhetoric was frequently tinged with racism and eugenics, justifying laws for women to "preserve the race," and it was prevalent in the 1908 defense of the ten-hour day for women in Muller. ${ }^{\ominus}$ During the twenties, social feminists dropped this rhetoric, and began to make very different arguments concerning women's need for a legal floor on their wages.

Social feminists had long known that curtailment of women's hours, secured in Muller v. Oregon in 1908, was meaningless without wage legislation. Hours limitation laws left women actually earning less than prior to this so-called reform, for working fewer hours meant less overall pay. A legal floor on wages was intended to bring working women up to a "living wage." In this spirit, women's minimum wage laws had been passed in eleven states, one federal district and one U.S. territory. ${ }^{10}$ By $1920 \mathrm{em}-$ ployers had begun serious legal challenges to these laws. The problem of litigation was not new, and the social feminist community mobilized in its now familiar fashion for the minimum wage test case, Adkins v. Children's Hospital.

But the Adkins case and the minimum wage issue itself would be treated differently from any previous women's labor laws. This was due to changes in social feminist ideology, which presented an alternative to the male standard for personhood in law, and to the direct economic nature of wage laws, which were seen in the twenties as a threat to the capitalist status-quo.

After suffrage, feminists split into two groups: those who agitated for an Equal Rights Amendment, and those who favored women's labor laws. Those who wanted "protection" for women, the social feminists, were turning their attention to economic equality, through living wages, which they emphasized over and above formal legal equality. They, too, were interested in women's equality, but they eschewed the ERA method and

For interpretations of women's labor laws as restrictive, see generally J. BAER, THE CHAins of Protection (1978); Erickson, Historical Background of "Protective" Labor Legislation: Muller v. Oregon, in 2 Women and the Law 155 (D.K. Weisberg ed. 1982); A. Kessler-HarRis, OUt to Work: A History of Wage-Earning Women In THE United States (1982). Historians have treated hours restrictions and night work elimination, as well as legislating women out of certain jobs, more thoroughly than they have minimum wage laws. Most scholars have assumed our understanding of wage laws should come from what we know about the other protective laws. But wage laws were different and they deserve attention separate from seemingly related issues.

9. Muller v. Oregon, 208 U.S. 412 (1908); Boris, Regulating Industrial Homework: The Triumph of "Sacred Motherhood," 71 J. AM. Hist. 745, 750, 754, 756 (1985).

10. Laws had been passed in Arizona, Arkansas, California, Colorado, Kansas, Massachusetts, Minnesota, North Dakota, Oregon, Utah, Washington, the District of Columbia and Puerto Rico. 
looked to women's labor laws as a means to substantive equality. Although we must see their proposals for economic equality as limited (or taking place within certain historical limitations), it is important to remember that these social feminists directly confronted the accepted economic order, and that they did so over gender issues. In the process they grappled with a notion of equality for women that relied on both women's similarity to and difference from men, an ideology they summarized in the phrase "industrial equality." 11

Social feminists placed their hopes for economic equality on minimum wage laws for women. Prior to taking up the minimum wage/living wage issue, social feminists advocated women's labor laws on the basis of a particular image of womanhood: the image of woman presented in Muller, for example, was weak, frail and dependent. She needed and looked to men for survival. Far from an economic being, she was a nurturant creature who needed to be protected in motherhood. In the 1920's, however, social feminists were no longer interested in arguing for women's wage laws along these lines. They did not present an image of frail women who needed higher wages because they were starving faster than men, or because women's weak constitutions suffered abuse more readily than men's. Rather, they presented the need for higher wages in light of a woman's value as a worker and her essential economic contribution to her family-a contribution that meant survival of all family members.

Social feminists of the twenties were moving away from an older style of reasoning that had lent support for Muller. Social feminism was changing; some women favored women's minimum wage laws because they believed these laws fostered female independence and self-sufficiency. They began to stress women's vital economic role in the family. Women were no longer viewed as necessarily and appropriately the dependents of men. Instead, social feminists drew public attention to the fact that many women had dependents under their care. A woman's responsibility to her dependents was more than nurture-it was economic.

Married women were of particular concern to social feminists. They believed, realistically, that most women married and bore children. In 1923 the question was not whether women ought to be spared debilitating

11. Previous historians have argued that the twenties inaugurated the "nadir" of American feminism. For this interpretation, see especially W. Chafe, The American Woman: Her Ghanging Social, Economic and Political Roles, 1920-1970 (1972). Recently Nancy Cott has argued this era was formative to modern feminism, seeing this as a crucial time on several levels. The most important for purposes here is the confrontation between differing definitions of equality. She also provides one of the more sympathetic views of social feminists who supported women's labor laws, especially because feminists who supported women's labor laws were concerned with social class as something that made women different from each other. N. CoTT, ThE Grounding of Modern FEMINISM (1987). Previous historians have called these women "social feminists" because they interpreted them as placing social issues above women's issues. See W. O'NeILL, supra note 2; J.S. LEMoNs, supra note 2. My reading of the social feminists suggests they did put "women first" as they said themselves, especially in their attempt to merge legal means of change with feminism. 
physical labor, or whether they needed to be protected by men-or by the state, as they had been in 1908. Instead, the problem for most women, social feminists declared, was that they faced two jobs: one in industry and one at home. Social feminists advocated women's labor laws as a means of easing this double burden.

As social feminists were recasting their ideas about work in terms of industrial equality, they were also redefining the perceived role of motherhood. Where motherhood had previously been portrayed as "sacred" enough that the state ought to protect it from women's labor, social feminists now considered the difficulties of the double burden in a new light. They denounced tendencies to compel dissatisfied mothers "to exact more" from themselves to find fulfillment in mothering. And household labor was seen as unjust, because it forced women to hold two jobs. As much as social feminists might have romanticized industrial labor, they were decidedly unromantic about motherhood. Motherhood was not empowering, and when combined with a job outside the home, it was overburdening. In the absence of maternity leave for workers, children had been born "in the factories, on the floor in the dressing room, if there was one."12 It was ironic to labor organizer Melinda Scott that in the face of this reality, another theory had been foisted on women-the glorification of motherhood. Critical of such theories about women, Scott declared, "Sacred motherhood. What a farce."1s Social feminists believed women's labor laws would help eliminate some of the work compounded by domesticity. ${ }^{14}$

Easing the double burden was not a matter of protecting unborn offspring, as it had been in Muller; it became a concern for the health and social participation of women themselves. That participation was wider than the domestic sphere, which social feminists had once defined as the appropriate social space for women; women's participation stretched after suffrage to include the polity.

While Muller had relied on the characterization of women as mothers, it also rested on women's disenfranchised political status. As nonvoters, women seemingly did not have the same contract rights as men. The ideology of free contract, dominant in the nineteenth century, limited legal interference in the "bargain" between employer and employee unless

12. Women's Bureau, U.S. Dep't of labor, Bull. No. 33, Proceedings of the Women's Industrial Conference 110-20 (1923) [hereinafter Proceedincs] (speech of Melinda Scott, Labor Legislation for Women).

13. Id.

14. Historians have argued that the purpose of these social feminists may have been to drive women from industry, but it seems clear in the twenties they advocated working as something that was good for women; in fact, low wages were seen to be more harmful than work itself. It was the problem of work and mothering that feminists tried to solve, and women's labor laws seemed the best solution to them. See, e.g., Proceedings, stupra note 12, at 34-41, 110-20 (speech of Margaret Dreier Robins, What Industry Means to Women Workers; speech of Melinda Scott, Labor Legislation for Women). 
there was danger to health, safety or welfare of the community. This police power exception to the rule lent itself more readily to women workers than to men in 1900 because women literally bore the future community and did not possess the same contract rights as men. ${ }^{15}$ Women, as nonvoters, had a different relationship to the state than men had, and therefore the state's involvement in women's contractual lives was legally feasible. After suffrage, other legal arguments had to be advanced. Ideas put forth in the women's wage case took their cue from an altered women's movement. ${ }^{16}$

Women's labor laws, in the spirit of 1920's industrial equality, raised new questions about female difference. When Muller was argued, women were primarily depicted as mothers, but also as people with inferior political status. After suffrage, social feminists argued that women were oppressed by the double burden, different because they had less money, and physiologically distinct only in childbearing. Moreover, women were now "full citizens" and they had the same republican rights as men. But women needed special provisions to exercise those rights. ${ }^{17}$

It was this fullness of citizenship, the exercise of republican rights, that women had gained with suffrage. The full meaning of those rights for working women was possible only through industrial equality. "As women . . . and as voters" it was appropriate to "agitate" for women's labor laws, because women had the right to "differ" from men. ${ }^{18}$ That right often revolved around maternity. Since "men [were] ineligible" for maternity welfare, as Florence Kelley was fond of pointing out, it made sense to legislate only for women. Maternity may have been the only physiological difference relevant to these matters, but some social "adjustment" to maternity was necessary if women were to have "equal fullness of citizenship with men."18

It seemed to social feminists in the 1920 's that the best way to make

15. On women and contract rights, see Stanley, Conjugal Bonds and Wage Labor: Rights of Contract in the Age of Emancipation, 75 J. AM. Hist. 471 (1988).

16. See Muller v. Oregon, 208 U.S. 412 (1908), for the legal argument that denied nonvoting women full contract rights. "Free contract," of course, meant the opportunity to bargain for one's own conditions of labor, however remote victory may have been for the worker. It is here that the experience of men and women diverged: men bargained for their hours of labor; women's were set by the state. The crucial difference, legally, was suffrage. Women, however, continued to be in a relatively weak bargaining position because they were less frequently organized into unions. This situation remained fairly stable after suffrage as well. Men, ironically, had won their own state regulated hours, despite the fact that they held the right to vote. Bunting v. Oregon, 243 U.S. 426 (1917); The Case for the Shorter Work Day, Brief for Defendant in Error, Bunting v. Oregon.

17. Nat'l Consumers' League, the Case for Special Legislation for Women Workers (n.d.) [hereinafter NCL, SPECial Legislation] (in Women's Bureau Records, Record Group 86, Correspondence 1919-1948, Office of the Director, Women's Organizations, at National Archives, Washington, D.C.).

18. Id.

19. J. Hicks, Special Legislation for Women in Industry (1927) (pamphlet of the Committee on the Legal Status of Women, National League of Women Voters, Box 260, in Papers of the National Woman's Party, at Manuscripts Division, Library of Congress, Washington, D.C.); Kelley, supra note 1. 
those social adjustments was through legal attention to difference. Women's labor laws were one means of providing that attention; they were the practical expression of the ideology of industrial equality.

\section{Industrial Equality: Social Feminism in the 1920's}

Social feminists who supported women's minimum wage laws did so because they wanted to correct women's inferior status and lower wages. It was this kind of attention to difference, one that sought separate laws for women to bring them up to "industrial equality," that was attentive to women's double burden, women's devalued labor, and hindrances to women's political participation. These women were eager to extend equal rights beyond suffrage, but they stressed that positive action was needed to get closer to actual equality, since women were held back by their distinct social role. They believed that the necessary action was best addressed through legal channels. After all, it was through law that they had won the right to vote and had gained previous protective labor laws.

The National Consumers' League, the National Women's Trade Union League, the League of Women Voters and the Women's Bureau were the primary social feminist organizations in the 1920's, and the women who staffed them believed strongly in equality for women. Even though they campaigned against the Equal Rights Amendment, they had a profound belief in the ability of law to provide equal rights for women in society. Advocating the women's minimum wage as part of this political campaign, they attempted to correct social and economic inequity through legislation and litigation that focused on bringing women's labor standards up to a new level.

This practice of invoking different treatment to achieve similar results was the keystone of industrial equality. The League of Women Voters announced its belief that "equality of opportunity does not and cannot mean identity of opportunity." ${ }^{20}$ If women, as unequals, were treated the same as men, then women would not fare as well. Women's lower wages, their relative lack of skill and the fewer opportunities open to them required some kind of positive action. Women's labor laws were one such action; they might "raise the position of women in industry to one more nearly approaching equality with that possessed by their male fellow workers." Far from "discrimination," women's minimum wage laws would inch women toward "equal industrial footing" with men. ${ }^{21}$

Removing women's "economic disabilities" was not easily accomplished, and social feminists did not always believe legislation alone could

20. Definition of Position of National Woman's Party and National League of Women Voters on Special Legislation (n.d.) (Series 2, Box 98, in League of Women Voters Collection, at Manuscripts Division, Library of Congress).

21. J. Hicks, supra note 19. 
do the job. Women's labor laws were once part of a proposed constellation of solutions, including education, technical training and union organization. ${ }^{22}$ But male unionists shunned the prospect of women in their unions-or even separate unions for women; the law, conversely, seemed potentially open to upholding legislation for women on the grounds that they were different from men. Women's labor laws appeared attainable, and despite the fact that social feminists had to spend years securing them, gaining the laws provided social feminists with political legitimacy. ${ }^{23}$ Women from the League of Women Voters acknowledged that legislation was "remedial," addressing "results of economic disabilities," not attacking the cause, but also insisted that "as long as these causes remain, so will special legislation be necessary." "24 One of the most important causes, social feminists were aware, was "persistence of the traditional attitude toward women's work and education."2s

A legally mandated increase in wages might begin to correct traditional attitudes which suggested that women's labor was worth less than men's. Positive action to compensate for women's economic inequality was dependent on advocacy by women, for women. Dr. Anna Howard Shaw, head of the Women's Division of the Council of National Defense, eagerly declared that " $[t]$ he time has come when it is neither the right of men, nor the duty of men, nor justice for men to decide problems of work for women." ${ }^{28}$ Mary Anderson, directer of The Women's Bureau, was so struck by these words that she had them printed on a card she carried around with her. ${ }^{27}$ Indeed, locating women's labor laws within the province of the women's reform community seemed the best way to keep the ideology of industrial equality safe. But there were limits to this safety, and Anderson recognized the dangers: "[ $t$ ]he men always felt they were inferior if they did not get higher wages than women," Anderson recalled, and one employer told her if his male and female workers were "paid ...

\footnotetext{
22. Johnson, Woman Citizen, Aug. 9, 1924, at 17.

23. Despite pronouncements about unions, most of the groups focused on legislation. It had the benefit of concrete success, and it offered social feminists access to the political and legal institutions, and formal institutions in turn offered legitimacy for social feminism when they won. Even the Women's Trade Union League, which had always prioritized unionization, reluctantly admitted legislation and litigation was a better course in the 1920's, because it seemed more attainable. A significant aspect of NWTUL in this period was that it was under the leadership of working-class women. This undoubtedly contributed to increased insistence on the value of women's labor. On the Women's Trade Union League, see N. Dye, as Equals and as Sisters: Feminism, The Labor Movement, and the Women's Trade Union league of New York (1980); E. Payne, Reform, Labor, and Feminism: Margaret Dreier Robins and the Women's Trade Union league (1988).

24. Johnson, supra note 22.

25. Id.

26. Shaw, Remarks before War Labor Board, quoted in M. ANDERson \& M. Winslow, Woman at Work: The Autobiography of Mary anderson as Told to Mary Winslow 107 (1951)

27. M. ANDERSON \& M. WinsLow, supra note 26 , at 107.
} 
the same there would be a revolution. There is a tacit understanding" that women would be paid less. ${ }^{28}$

Wage laws, too, had their limitations. Despite the fact that social feminists insisted on female self-sufficiency and the role of women as supporters of families, the standard "living wage" was based on the needs of a single woman living away from home, with no one to support but herself. $^{20}$ Although social feminists made it known that women often supported others, the wages set by minimum wage laws did not begin to address the economic troubles besetting women with dependents. Social feminists of the twenties took an important step in recognizing the social and economic roles of women, but their wage scheme suggested they believed women with dependents should have acquired a partner to share in breadwinning. This position assumed the benefit of reinforcing traditional family values. Yet, simultaneously, it advanced the value of women, and encouraged independence for at least some (single) women.

On the other hand, social feminists sometimes pushed beyond their own limits. One of their proposals suggested that part-time work should pay twice the hourly wage of full-time work. Because women who worked part time did so to spend the rest of their time with domestic responsibilities, social feminists wanted to compel employers to compensate for this dual role. ${ }^{30}$ Once again, social feminists accepted the double burden, but suggested rearrangement of work-time and compensation which would allow women to fill the two roles without suffering economic loss, and without being required to construct a male biography of their working life. ${ }^{31}$

This proposal goes a long way toward explaining what social feminists

28. Id. at 104. As the province of a women's community, these social feminists battled for the minimum wage in a style of separatism historians have located prior to suffrage. Though this kind of separatism broke down during the New Deal, I find evidence of women's political culture, at least in the early post-suffrage years. This separatism, very much a source of strength, was tempered by a certain degree of male deference. For example, though Florence Kelley actually ran the National Consumers' League, the President of the organization was always male. In this period the president was Newton Baker, soon to be replaced by John Commons. Law also opened possibilities for integration with the political system, where women had finally gained formal access with suffrage, but it also limited and shaped social feminist ideals. See Freedman, Separatism as Strategy: Female Institution Building and American Feminism, 1870-1930, 5 FEMINIST STUdies 512 (1979); Baker, The Domesticization Of Politics: Women and American Political Society, 1780-1920, 89 AM. HIST. REv. 620 (1984), for the significance of these two phases of American feminism and arguments that 1920 was the watershed. On Florence Kelley's background in a women's political culture, see Sklar, $\mathrm{Hull}$ House in the 1890s: A Community of Women Reformers, 10 SIGNS 658 (1985) [hereinafter Sklar, Hull House]; Sklar, Why Were Most Politically Active Women Opposed to the E.R.A. in the 1920s?, in Rights of Passage: The Past and Future of The E.R.A. 25 (J. Hoff-Wilson ed. 1986). Sklar finds that Kelley and other women at Hull House cooperated with men.

29. Perhaps it is no coincidence that these were the women social feminists admired most and with whom they most identified, since most social feminists during the period were single.

30. D.C. Minimum Wage Board, A Study of Wages of Women Employed as Cleaners, Maids, and Elevator Operators in Office Bulldings, Banks and Theatres and as Car Cleaners in the District of Columbia (1920).

31. On the need of women to construct a "biography" similar to a man's to gain equal treatment, see C. Mackinnon, Feminism Unmodified: Discourses on Life ANd LAw 32-45 (1987). MacKinnon explains that "difference" always indicates a power relationship. 
meant by industrial equality, and why they saw this attention to women's difference from men as a means to achieve equality. They accepted the double burden as reality. What they were looking for was a way to make a doubly burdened life more livable. Reduced hours of labor created time for children, and higher wages produced money to support those children. Social feminists believed it was possible to convince the state-through legislation and litigation - to cooperate in this scheme, in the name of feminism and the family. To them, this was "industrial equality" and justice. They also saw it as realistic.

What they viewed as unrealistic, however, was changing family relations so that men would shoulder half the burden of domestic responsibility. They called that proposal a "utopian dream." Although it was an appealing dream, they were thoroughly convinced that men were not going to change. It seemed easier to alter the terms of an industrial economy than to transform conditions of personal relationships. ${ }^{32}$ Constant awareness of the need for change on the domestic level, coupled with refusal to try to alter these conditions presented something of a strain within social feminists' "realism." Often what they perceived as realistic was any issue that could be legislated and litigated. ${ }^{33}$

One issue social feminists consistently wanted to confront was sex discrimination. They chose a strategy that addressed differences in women's working experiences, over and above equal treatment, in order to elevate women to equal status. They hoped women's labor laws would lead to better jobs, rather than restrict women, believing that "a labor law which accomplishes these results has the psychological effect of increasing the sense of power and independence of women in industry." ${ }^{44}$ Social feminists perceived labor laws not only as a remedy for past wrongs, but also as a means of empowering women workers.

Industrial equality suggested to social feminists the significance of work itself for working-class women. Work, it seemed, could bring women joy and fulfillment. Middle-class women were impressed by the way women

32. See generally Brief for Appellants, Adkins v. Children's Hosp., 261 U.S. 525 (1923) (Nos. 795 \& 796); ProceEdings, supra note 12, at 66-77, 120-28 (speech of Mary Gilson, What Women Workers Mean to Industry; speech of Merica Hoagland, Labor Legislation for Women).

33. In keeping with the ongoing theme of realistic feminism versus theoretical equality, posed by the National Woman's Party with the Equal Rights Amendment, Barbara N. Grimes discussed "negative freedom" posed against "positive freedom." Grimes, Protective Legislation for Women and the Twentieth Amendment, Bull. Cal. Civic League of Women Voters, March 1924, at 1.

34. M. Thomas \& M. Van Kleeck, Second Statement of the Committee Appointed to Present Considerations Affecting An Equal Rights Amendment; J. AM. Ass'N U. WomEN, Jan. 1925, at 19 (summary of Van Kleeck's viewpoint). As participation in the legal system had been an empowering experience for middle-class women, social feminists were interested in a wide variety of legal solutions to women's problems. As an attempt to achieve equality, they sponsored in this period over twenty bills to correct women's unequal legal status in nearly every state. See NaT'L LeAgue of Women VOTERS, supra note 1 . It follows they believed the effects of the laws could be just as empowering for the women they were created to help, but legal action provided political access for the social feminists only, and they took matters out of the hands of the working women for whom they legislated. Unions would have given working women more of a voice and greater access to democracy. 
had "become an essential factor in a sphere formerly considered not to be theirs." 35 Celebrating this role for women, social feminists combined a "joy of work" viewpoint with the "essential nature" of women's work. Where they had once advocated women's hours limitation by subordinating women's labor to the family, they now argued that women made a vital contribution to family income and were often solely responsible for the support of others. ${ }^{36}$ The answer to women's double burden was not to be found in "closing the doors of industry to women." Instead, women deserved to be rewarded for their independence, responsibility and value; they were entitled to "dignity" in their work. Proceeding on the assumption that most, but not all, women married, and that not all married women had children, they began to depict working women as more than caretakers. Women, they insisted, were not to be characterized only as mothers. ${ }^{37}$

Veteran labor organizer Agnes Nestor scolded these middle-class women, dissenting from the "joy of work" notion: "It's all right to talk about the joy of work. I know the 'joy of work.' When I began working I did not want to hear the whistle blow. But that was before I had worked a long enough number of years to feel the strain ... that I did eventually feel and under which I broke."ss

Middle-class and working-class women may have had differing attitudes about work, but they were able to agree on the burden of the double day. Those women who were called to the "double draft" of industrial labor and household work were operating at a disadvantage. By comparison, wage-earning men were a "privileged class;" they had far fewer responsibilities at home than did their working wives. Women faced the choice either of neglecting their families for the sake of their own independence or of catering to family needs, while sapping their own "vitality."39 To achieve citizenship on par with men, women needed legal measures to alleviate their double burden. Rather than protect women in motherhood, social feminists worried that women were "stunted" by their lack of civic

35. See Proceedings, supra note 12, at 24-34, 177-78 (speech of Mary Van Kleeck, What Industry Means to Women Workers; Resolution, Women's Industrial Conference, January 13, 1923).

36. Women's Bureau, U.S. Dep't of Labor, Bull. No. 30, The Share of Wage-Earning WOMEN IN FAMILY SUPPORT (1923).

37. See Proceedings, supra note 12, at 24-34, 66-77, 85-91 (speech of Mary Van Kleeck, What Industry Means to Women; speech of Mary Gilson, What Women Workers Mean to Industry; speech of Sophonisba Breckenridge, The Equal Wage).

38. Id. at 178-84 (speech of Agnes Nestor, of the National Glove Workers of America). Although historians have criticized social feminists for refusing to recognize women may have worked for independence, sociability and enjoyment, it is true that middle-class women in this movement often looked upon industrial labor as "exciting." It was working-class sisters who called them on it. For criticism that social feminists saw working-class women as "beasts of burden," see generally N. CoTT, supra note 11, at 117-42; see also J. Sealander, As Minority Becomes Majority: Federal Reaction to the Phenomenon of Women in the Work Force, 1920-1963 (1983); W. WANDersee, WOMEN'S WORK AND FAMILY VALUES, 1920-1940 (1981).

39. See NCL, Special Legislation, supra note 17. 
involvement, and they urged facilitation of that participation, lest the public be deprived of their viewpoint. As voters, women were "for the first time .. . sharing in the government," and so the National Consumers' League declared its new task for women: "We must see to it that industrial life is compatible with citizenship in democracy."

Women were also different from men because they earned lower wages, a problem compounded by their being classed into the least skilled and most draining jobs. They earned "just enough to keep body and soul together," and this didn't leave much left for "social questions." Political citizenship was contingent on "industrial citizenship," and thousands of women did not exercise their rights "largely because of economic conditions." 41 Women's labor laws were an attempt to create a healthy workplace, with high enough wages, so that working women could enjoy rights more often exercised by men. In the wake of suffrage, this was separate treatment to create equality and political integration. ${ }^{2}$

\section{1920's Women's Political Culture: Separatism and REPUBLICANISM}

The minimum wage was not exclusively a social feminist initiative. Reformers such as John Commons and John Andrews had, since the turnof-the-century, put a minimum wage on the agenda of labor law reform. They shared with social feminist Florence Kelley the goal of achieving labor laws for all workers to limit the working day, to provide a living wage, and to secure healthy, safe workplaces.

The prevailing judicial treatment of labor law, however, convinced reformers that they would have a better chance of validating labor laws in court if these laws were exclusively for women. ${ }^{43}$ As an opening door, reformers introduced labor legislation for women, hoping that once these laws were entrenched, labor laws for men would be more easily secured. Within this reform community, however, women's laws quickly became

40. Id.

41. Women's Bureau, U.S. Dep't of Labor, Press Release (Jan. 20, 1926) (Box 234, in Papers of National Woman's Party, at Manuscripts Division, Library of Congress).

42. For examples of separate treatment to gain equal participation, see Kelley, supra note 1; J. Hicks, supra note 19. Far from relying exclusively on "expediency arguments" of the pre-suffrage years, as suggested by Felice Gordon in After Winning: The Legacy of The New Jersey SufFRAGISTS, 1920-1947, at 19, 58-62, 103-04 (1986), these women were relying on "justice arguments" as well. As believers in equality for women, they embraced republican ideology. And they blended their republicanism with uses of difference and separateness in the expediency style. Their ideology can be characterized as a melding of both styles of reasoning. See A. KRADITOR, The IDEAS OF THE Woman Suffrace Movement, 1890-1920 (1965), for a background on suffrage ideologies as "expediency" and "justice." See also N. CoTT, supra note 11, for an updated treatment of this problem.

43. In Lochner v. New York, 198 U.S. 45 (1905), the Supreme Court denied the validity of a statute regulating the hours of male bakers, but it hinted that it might treat hours legislation for women more favorably. Reformers followed with Muller. For apt discussions of this, see J. BAER, supra note 8; S. Lehrer, Origins of Protective Labor Legislation fOR WOMEN, 1905-1925 (1980). 
women's work, and it was the social feminists who took up the task of education, legislation and publication on protective labor legislation for women. As women oversaw initiatives on women's hours limitation, restriction of nightwork and women's minimum wages, reform-minded men worked to gain "social insurance," such as workmen's compensation, a reform initially geared only toward men. ${ }^{44}$ Reform work became segmented by gender, and in the process women developed their own political culture. This women's political culture was a source of strength to social feminists, and it was a device to integrate themselves into the larger (male) political community. ${ }^{45}$

In their women's political culture, social feminists formed their own consciousness of women's labor laws. Although the ultimate goal was labor laws for all workers, social feminists who focused primarily on woman- and child-centered issues found their own meaning in separate laws for women. To them, the significance of women's labor laws went far beyond opening the door for men-which was the legal-strategic reason separate women's laws were introduced first. They became a vehicle for a feminist goal: legal equality through difference. ${ }^{48}$

The struggle of early twentieth-century social feminists to reconcile work and family led social feminists to a viewpoint in 1920 that they had not anticipated in 1900. By the twenties, their ideology of womanhood had shifted considerably. Although social feminists were beginning to see men and women as largely the same, they also recognized important areas where women's experiences diverged from men's. Social feminists supported minimum wage laws based on a vision of women as equally capable as men, but nonetheless different. They sought wage laws for women as a way of raising women's earnings, and consequently their value in society. Women were most importantly different because they earned alarmingly less than men. But the legal ideology of separate labor laws relied on differences that were presumed permanent; women's double burden, perceived as unalterable, was a useful point to make in defending women's need for "protection." Accounting for both sameness and difference encompassed social feminists' ideology of industrial equality, which they promoted as a legal possibility for women's economic uplift.

Their ideology of industrial equality drew from two different strands in law, each derived from previous experiences. ${ }^{47}$ Fusing the two, they be-

44. See generally R. LUBove, supra note 7, at 52-65.

45. Sklar, Hull House, supra note 28; Nelson, The Gender, Race, and Class Origins of Early Welfare Policy and the Welfare State: A Comparison of Workmen's Compensation and Mothers' Aid (forthcoming in Women in Twentieth Century Politics (P. Gurin \& L. Tilly eds.)).

46. For background on this reform community, see two studies of women's labor laws, J. BAER, supra note 8; S. LEHRER, supra note 43. Neither author gives attention to how different these reform issues were for social feminists who participated in the process.

47. Bunting v. Oregon, 243 U.S. 426 (1917), the case that upheld regulation of men's hours of labor, made clear that men needed a shorter work day to participate in community affairs, to be good citizens. The standards of Bunting were hardly the standards of Muller, where women were in dan- 
gan to think that women could gain labor legislation which would prompt equality. Those laws, however, had only been validated for protection of community health and welfare, based on the rhetoric of sacred motherhood and preservation of the race. Rejecting that rhetoric, they began to attempt a definition of equality, etching out an equality theory from the traditions of republicanism and separatism. Republicanism, partly a constitutional tradition and potentially a radical force, grew out of suffrage, an experience shared by women who advocated women's labor laws. The republican aspects of their theory stressed egalitarianism and participation, or political power.

Social feminists also drew on the heritage of separatism, a part of women's political participation from the past. When women did not have the right to vote, they participated in politics from outside formal power sources to accomplish such diverse goals as prohibition and suffrage. From these two vantage points, social feminists saw separate labor laws for women as a way to achieve equal status for women through different treatment. They did not demand that women act like men; they wanted women to be equal to and different from men.

The twenties, the period when social feminists tried to merge the two concepts of equality and separation, were between two well-known phases of American feminism, which historians have called "separatism" and "integration." Separatism was characterized by nonvoting women, who were thought to be more pure than men because they did not participate formally in politics. But through a separate women's political culture, social feminists formed bonds with one another and exerted pressure for change from outside official power sources. ${ }^{48}$ In the period of integration, the thirties, social feminists gave up their separate culture for formal as well as informal places in the New Deal government. ${ }^{49}$

When social feminists tried to merge the theory of separatism (women's differences from men) with the theory of integration (republicanism), they attempted to bridge the distance between two political styles, the old and the new, for American social feminism. Their merging of these two concepts was far from perfect, and it generated a great deal of ambivalence. It is significant, however, that they tried to work with a theory of equality that did not assume sameness as a standard for equality. For them, equality and difference were not oppositional concepts; social feminists saw no

ger of damaging their reproductive organs and neglecting their children. Social feminists had been involved in Bunting, and it is very possible that after suffrage they believed they could legitimately argue for women's labor laws along the lines of Bunting. Unfortunately, their attorney, Felix Frankfurter, did not quite make that attempt.

48. See Baker, supra note 28 , for discussion of women's voluntary activities outside of formal power structures as being more than outside, but actually "above" official power sources.

49. On this process, see generally Freedman, supra note 28 , for a view that the period of separatism was preferable; but see S. WARE, Beyond Suffrage: Women In THE New Deal (1981), for a more positive reading of women's political integration. 
need to justify their coexistence. Lawyers and judges, in contrast, did not see this feminist theory very clearly.

Social feminists still claimed a right to state protection of women's labor for reasons that set women apart from men-for gendered reasons-but they also proudly drew on women's full citizenship and began to include enjoyment of full participatory rights as a reason to protect women. Combined with notions of women's independence, self-sufficiency and the benefit of work was recognition that many working women were hindered in these "rights" by the double burden, exploited labor and consequent low wages. All these issues encouraged social feminists to think in terms of industrial equality, and with suffrage behind them, they believed they had all the more reason to think prospects for a women's minimum wage were better than ever.

As a generation of social feminists historically between separatism and integration, it made sense that the ideology of industrial equality integrated sameness and difference. Somewhere between full participation and a place "above politics," these social feminists tried to reconcile conflicting strains from each world. Their ideas reflected their own social and political reality. But they were stuck with old legal methods for their new ideas, and it was a struggle to maintain a style of reasoning for minimum wages that had been successful with hours restriction. One problem was that social feminists simply no longer believed in the older characterization of women. Although they still advocated distinct legal measures for women, they did so to bring women into the former male sphere of power, and to give women advantages formerly reserved for men. Social feminists aimed to bring their new concepts to the Supreme Court for validation, as they had done before, and they expected their lawyerly sympathizers to comprehend this goal. But lawyers adhered to the prior vision of women which had guided previous protective labor laws: a vision that set women apart from men because they were different and, therefore, unequal.

\section{LAWYERS AND WOMEN'S EQUALITY}

The 1920's discourse on women's equality contained three alternatives. Competing for dominance were the social feminist vision of industrial equality, the National Woman's Party campaign for the Equal Rights Amendment, and the view from the male legal community. The liberal lawyers who supported separate women's labor laws were allied with, but sharply distinct from, social feminists. Dividing the movement along gender lines, these men had no commitment to industrial equality. To them, separate treatment meant inequality-something they favored.

Whereas social feminists were developing a critique of equality through identical legal treatment male lawyers tended to oppose women's equality of any kind. Social feminists favored women's labor laws as means to 
equality, and they were troubled by posed contradictions between formal legal equality (ERA) and separate treatment (women's labor laws). Contradiction between these two methods was partly imposed by lawyers. To them, women's equality was a liability, denying what was in their view an exalted status for women in society.

Most lawyers in 1923 viewed the ERA as a threat to privileges women enjoyed based on inequality. Equality would eliminate better treatment of women, and therefore hurt them. One lawyer thought the "chief difficulty with the amendment seems to be the word 'equality." "so Lawyers stressed differences between men and women as a "well recognized fact" which mandated "special and restrictive laws" for women." Social feminists were not uncomfortable with the word "equality," which they themselves used; they were only concerned with how equality was to be defined. Rather than speaking of women's labor laws as restrictive, they had begun to advocate them as a means to empower women, especially through higher wages. But their legal advisors disagreed. For them, the purpose of these laws had nothing to do with "civil and legal rights of women," even though social feminists had defended the wage law as a matter of full enjoyment of "rights." Women's labor laws, to lawyers, served only to protect women from "hardships, wrongs and evils." stressed physiological differences between the sexes, which social feminists were then downplaying. And to lawyers, accounting for differences meant precluding equality. ${ }^{.8}$

Women in the League of Women Voters and Consumers' League consulted with several lawyers in their reform circles on the question of equality. They wanted to know the extent to which women's labor laws and formal equal rights were contradictory. Although social feminists had begun to see women's labor laws as promoting industrial equality, their lawyers were forthright in asserting that previous protective laws had been based on inequality. Muller $v$. Oregon, declared one lawyer, would never have been successful if it had not been premised on women's inequality. By upholding women's employment statutes, the court "did create legal inequalities in respect of sex." 154

50. Letter from Robert Szold to Florence Kelley (Jan. 4, 1922) (Reel 51, in National Consumers' League Collection, at Manuscripts Division, Library of Congress).

51. Letter from James R. Garfield to Mrs. Gifford Pinchot (Feb. 6, 1922) (Series 2, Box 102, in League of Women Voters Collection, at Manuscripts Division, Library of Congress).

52. Id.

53. Letter from William Draper Lewis to Mildred S. Gordon (Dec. 5, 1922) (Series 2, Box 102, in League of Women Voters Collection, at Manuscripts Division, Library of Congress).

54. Letter from Francis Fisher Kane to Ethel Smith (Jan. 12, 1922) (Series 2, Box 102, in League of Women Voters Collection, at Manuscripts Division, Library of Congress). Other liberal lawyers made their opinions known to social feminists. See, e.g., Letter from Roscoe Pound to Alice Paul (n.d.) (excerpt, Reel 16, in Margaret Dreier Robins Papers, in Papers of the National Women's Trade Union League and Its Principal Leaders, at University of Florida, Gainesville, FL); Letter from Roscoe Pound to Felix Frankfurter (Feb. 3, 1922) (Series 2, Box 102, in League of Women Voters Collection, at Manuscripts Division, Library of Congress); Letter from Edwin Borchard to 
Felix Frankfurter, the Consumers' League lawyer, who would argue Adkins before the Supreme Court, was one of the staunchest opponents to women's equality, in part because he was such an advocate of women's labor laws. To his legal mind, that meant favoring women's inequality. Declaring that the law must account for diversity in women's "nature," Frankfurter insisted laws should treat females sometimes as "persons" and other times as "women." Although social feminists often discussed women's diversity, they never saw it as a matter of nature; they instead viewed social roles and labor conditions as impediments to women's equality. Frankfurter's distinction between women and persons was a far cry from social feminists' claims of "women first" as an approach to women's predicament, but it also mirrored feminist ambivalence about sameness and difference.ss

Protective laws relied on separate treatment of men and women, and this both reflected earlier social ideals of womanhood and encouraged behavior that reinforced this ideal in the economic sphere. Lawyers who wrote on equality, even those who supported women's labor laws, expressed the dominant legal view in these matters. Separate treatment, legally, meant inequality. In part, hours restriction had been successful because American social feminism had been in accord with these legal principles and broader social outlooks. Although social feminists did not advocate women's inequality, they did stress women's separateness and difference. In so doing, they were able to gain women's labor laws. After suffrage, social feminism and the ideology of industrial equality were at odds with legal ideology.

In the twenties, while social feminism was in transition, women continued to speak about the women's minimum wage as a matter of equality. Social feminists-unlike their lawyers-did not see protection as "a sign of weakness or inferiority," rather its achievement indicated "the power and importance of women in industry." gains" 57 for women, which could be obtained, they theorized, not by adopting sameness in law and subjecting women to a "male standard," which would encourage inequality, but by stressing different treatment for similar results. ${ }^{60}$

Ruth Dadaunian (Feb. 22, 1922) (Reel 51, in Papers of the National Consumers' League, at Manuscripts Division, Library of Congress).

55. See J. Hicks, supra note 19; F. Frankfurter, Lawyers' Opinions (c. 1922) (Reel 51, in National Consumers' League Collection, at Manuscripts Division, Library of Congress).

56. Letter from Gertrude Besse King to Wenona Osborne Pinkham (Nov. 8, 1922) (Reel 53, in National Consumers' League Collection, at Manuscripts Division, Library of Congress).

57. Declaration Adopted by the Conference of Trade Union Women at the Call of the National Women's Trade Union League (Feb. 26, 1922) (Reel 51, in National Consumers' League Collection, at Manuscripts Division, Library of Congress).

58. Nat'l LEAGUE OF WOMEN Voters, supra note 1.

59. Miss Wing Raps Equality Bill, Ohio Press, Apr. 22, 1924; NCL, Why It Should Not PASs, supra note 1. "Identity" of treatment, they believed, was "restrictive," and they feared women 
There was a division between lawyers and social feminists. Although in advocating women's minimum wage laws, social feminists can be seen as attempting to feminize the law, lawyers remained resistant to that possibility. Frankfurter probably captured this best in his discussion of Crystal Eastman, a supporter of ERA "I am aware that Crystal Eastman once upon a time knew something about law, but that was long ago and far away. Now she disregards her former learning and writes as a 'feminist." "\$0 To Frankfurter, legal ideology and feminist politics were mutually exclusive, and his view was echoed by most male lawyers and judges: thinking like a lawyer excluded thinking like a feminist. Those who favored industrial equality assumed law and social feminism could be merged, and, in fact, made the merger the fundamental point of women's minimum wage laws. Frankfurter enthusiastically supported women's minimum wage laws, but the social feminist notion of bringing gender distinction to the law to promote equality escaped him. ${ }^{61}$

Law had its human conduits in this story. Social feminists such as Florence Kelley and Molly Dewson worked on the women's minimum wage test case through the National Consumers' League, a progressive organization which emphasized legal solutions to social problems. During the twenties their legal counsel was the ambitious lawyer Felix Frankfurter, whose tenure at the Consumers' League followed in the footsteps of his mentor Louis Brandeis. The method of sociological jurisprudence, often associated with Brandeis, was the calling card of the Consumers' League. Frankfurter was significant to Dewson and Kelley because he was to argue their case on behalf of women workers' wages in the Supreme Court. But he was more than that. He was the emissary of legal ideology, welltrained and versed in dominant legal thinking. His knowledge comprised an unknown deficit for the social feminists' cause; it embodied the very limitation of the law for social feminism.

Lawyers represented, if nothing else, the received legal wisdom, and they hinted at what was to come in Adkins, where the social feminist

being subjected to a male legal standard. If women were dominated by the "male norm" they would not be able to gain equality. Male preferences, they were concerned, might be legally invoked for women if there were not separate standards, and women would then have no choice in the matter. This "negative freedom" they posed against "real freedom," and it provided a critique of law as male defined as well as a gender sensitive alternative. See Grimes, supra note 33.

The League of Women Voters announced: "The League believes that equality of opportunity does not and cannot mean identity of opportunity." Definition of Position of National Woman's Party and National League of Women Voters on Special Legislation, supra note 20. The Consumers' League asked in one Bulletin, "What are included in 'rights?' Does equal mean identical? What does it mean?" Bull. Consumers' League E. PA. (March 1924).

60. Frankfurter, The Equal Rights Amendment, New Republic, Nov. 24, 1924, at 20.

61. For an insightful discussion of how patriarchal values shape litigation structure as well as doctrine, see White, Unearthing Barriers to Women's Speech: Notes Toward a Feminist Sense of Procedural Justice (forthcoming in AT THE Boundaries of LAW: Feminism and Legal Theory (M. Fineman ed.)). White advances the idea that feminists might be able to overcome patriarchal doctrine and procedure through a gendered approach to law. 
claim to industrial equality was incomprehensible to the justices. Significantly, this was true even though the Court was dominated by conservative judges who were politically distinct from the liberal lawyers in alliance with Consumers' League leaders.

Contemporary liberal observers feared a conservative mood at the Court in 1923, especially in light of recent anti-labor decisions and several conservative Harding appointments. "The economic complexion of the Court will have to change materially before we can hope for greater liberality," one lawyer told the League of Women Voters. He suspected that antilabor sentiments, combined with the proposed ERA, which cast women's labor laws as inegalitarian, were certain to bring an adverse decision in Adkins. ${ }^{62}$ Yet he failed, as did all other observers, to see that suffrage was equally threatening, in the eyes of the law, to women's labor laws. Although social feminists feared the effect of the ERA on the women's minimum wage, it was suffrage that had actually changed the legal status of women and had encouraged social feminists to significantly alter their reasons for defending the women's minimum wage. And it was suffrage, itself, that could be turned against these laws.

Social feminists were attempting to influence law, as they believed their past advocacy of women's hours laws and suffrage had done. However, legal ideology had also influenced social feminists. Their success in previous litigation had partly relied upon women being in a separate legal class, as the Muller decision had noted. ${ }^{63}$ Other factors, too, had put previous women's labor laws in a favorable light. Putting motherhood first among women's roles and stressing women's physical inferiority was not a challenge or a threat to the judicial outlook on gender roles. Women's differences from men suggested to the Supreme Court and to dominant legal thinking that women were unequal. Now social feminists wanted to rely on difference to gain special treatment that might, in their view, encourage legal equality. This was a different matter. Influenced by suffrage and the equal citizenship it implied, they were drawing on a strain in American law that probably bore little relationship to the police power, which had justified previous protective labor legislation.

The police power was an important exception to "free contract" ideology, which enabled the state to intervene in the bargain between employer and employee in order to mandate certain conditions of labor concerning the health, safety or morals of the community. Women's differences, both physiological and social, became the basis of police power exceptions in women's labor laws, and the community interests protected were often the real or potential offspring of the working women, rather than the women

62. Letter from Francis Fisher Kane to Ethel Smith, supra note 54. For examples of anti-labor decisions during the previous year, see Am. Steel Foundaries v. Tri-City Cent. Trades Council, 257 U.S. 184 (1921); Truax v. Corrigan, 257 U.S. 312 (1921).

63. Muller v. Oregon, 208 U.S. 412 (1908). 
themselves. In part, the courts were sympathetic to this argument because disenfranchised women were seen as wards of the state, which made it easier for the courts to justify legal interference in the "bargain" between employer and female employee. ${ }^{.4}$

As the social feminist acceptance of female dependency gave way in the 1910 's to a new vision of industrial equality in the 1920's, social feminists found themselves arguing for women's minimum wages in a style no longer compatible with the police power rule they had previously used to their advantage. They now faced a new legal problem. How were they to establish a link between the police power and yet remain true to their ideology of industrial equality? The brief created by Molly Dewson was an attempt to mediate this political problem.

\section{Social Feminism and the Adkins Brief}

By 1923 when the women's minimum wage test case, Adkins v. Children's Hospital, reached the Supreme Court, the character of the wage issue was clearly separated from other women's labor laws. Social feminists, in their new vision of economic rights and industrial equality, were challenging the established boundaries of state intervention in the economy. Their feminism had led them to a direct departure from the economic status quo.

Hours legislation and health and safety measures involved intervention in the economy, but the cost to employers could always have been made up in reduced wages. A state-imposed floor on wages signaled to conservative employers, and to a majority of the Supreme Court, a "redistributive" culmination to the era of "progressive" reform. This redistributive capacity was, of course, very moderate, but on the heels of the Red Scare it raised the specter of socialism. Enemies of minimum wage laws for women argued that these laws involved "changing the rules" of economic principles, and that they were illegitimate because they were concerned only with money. If low wages were dangerous, they offered, then so was capitalism itself. The Constitution, they feared, was being used to tamper with capitalism. ${ }^{85}$

64. But these laws also rested on a certain ideology of womanhood, which was compatible with both the uses of the police power and women's inequality. My interpretation of the police power in women's labor laws is influenced by J. BAER, supra note 8.

65. See generally Appellants' Reply Brief at 4-13, Children's Hosp. v. Adkins, 284 F. 613 (D.C. Cir. 1922) (No. 3438), affd, 261 U.S. 525 (1923). Many reformers were trying to make the same point. Labor law leaders such as John Commons and John Andrews of the American Association for Labor Legislation wanted, in fact, to save capitalism from self-destruction by protecting workers' health and by "humanizing" industry enough to prevent working-class revolution by establishing industrial peace. See generally Ross, Socialism and American Liberalism: Academic Social Thought in the 1880's, 11 PERSP. AM. Hist. 5 (1977-78). Social feminists were involved in "changing the rules" of the economy for women, but over and above this they were interested in new models for women's equality, other than ERA, which led them to see these laws as economic justice for working-class women, and they therefore had reasons different from their male counterparts for supporting this 
Both sides brought their competing views of economic policy to the Supreme Court. While economic policy issues dominated the case, and the social class issues raised by it are very significant, judicial comment on women's legal status is equally important to understanding Adkins.

The brief presented by the National Consumers' League in Adkins represented the culmination of a generation's work and evolving ideas on women in society. Meticulously prepared by Molly Dewson, it drew on many social feminist claims to industrial equality, selecting pertinent data from amassed investigations of women's organizations. In preparing the brief for the Consumers' League, Dewson did most of the sociological and economic work for attorney Frankfurter, who worked on the legal arguments and appeared in court. ${ }^{\boldsymbol{B \theta}}$

Dewson told the Court that work was not degrading to women. Where previously social feminists had argued to preserve women's health from the horrors of industrial labor, now they argued that work itself was far less damaging to a woman than low wages. No longer interested in accepting female dependency or curtailing opportunities, social feminists now favored expanded rights for women in the form of a right to decent wages. But the brief, and this argument, were limited by the need to prove a police power exception to free contract.

To convince the Court that a police power exception was compatible with women's minimum wage laws, Dewson had to demonstrate women were separate from men in order to distinguish them as a "class" needing protection. After suffrage, this was more difficult to do, because women had the same political rights as men. Although potential starvation represented an important threat to a woman's health, social feminists saw the need for minimum wages as more than a safeguard to health. Viewing the state less as a caretaker and more as an agent of freedom for women, social feminists wanted to transform dependency into an alternative form of equality. Social feminists wanted women's minimum wage laws not primarily to protect women's health, but as an answer to working women's economic disadvantages. ${ }^{67}$

method. These economic issues, and the two-sided motivation for them, had a great deal to do with why the police power might not have applied to wage laws in 1923. See generally WOMEN's BUREAu, U.S. Dep't of Labor, Bull. No. 17, Women's Wages in Kansas (1921); Women's Bureau, U.S. Dep'T of Labor, Bull. No. 23, The Family Status of Breadwinning Women (1922); Brief for Appellants, Adkins v. Children's Hosp., supra note 32, at 880-82, 902-06.

Some historians have argued that reformers were equally afraid of socialism, that labor laws were their method of preventing it, and that protective labor laws succeeded only so long as they were necessary to preserve capitalism. See S. LeHRER, supra note 43 . That analysis does not take into account the significance of these cases in terms of gender, nor does it credit social feminists with pushing beyond the needs of capitalism, and therefore, failing to play into employers' hands by stressing industrial efficiency as a reason to welcome these laws. Feminism and capitalism were at odds.

66. S. Ware, Partner and I: Molly Dewson, Feminism, and New Deal Politics 97-102

(1987), details the relationship between Dewson and Frankfurter.

67. On the problem of claiming rights when there are none, see Hartog, The Constitution of 
In their brief, social feminists celebrated the value of women's work. As economic and social justice, "underpayment of large groups of women" was "contrary to all standards, economic as well as social." The minimum wage offered the "first step toward the elevation of women in industry to a plane where due recognition is given the value of their work." selected material that stressed women as breadwinners, with family members dependent on their support. In an effort to overcome the long standing myth that women worked only for "pin money," she relied on reports that stressed women's labor as crucial to family support. ${ }^{68}$

If husbands were absent or unemployed, Dewson argued, women worked to support children. If a man was disabled or had deserted his wife, she was solely responsible for her family. Young single women often worked to support parents, a responsibility young men often escaped. Divorced or widowed women supported themselves and their children as well; they had no other source of income, and their own wages had to suffice. In sum, women made an important economic contribution to family life, whether they were single or married, and social feminists vigorously pointed to this in their brief. A community larger than women themselves needed a woman's wages. Older assumptions that only men shouldered such economic responsibility did not apply. ${ }^{70}$

The double burden separated women from men, the social feminists' brief declared, and part of the difficulty was childcare. To afford such care for their children, many women needed increased wages. Working women were shouldering the "double social significance," but the solution was not depending on someone else. They simply needed more money to afford their many dependents, and they needed fewer hours of labor to allow more time for caregiving. Social feminists were attempting to alter the dominant culture's view of the American family. They did not challenge the family arrangement; instead they emphasized women's contribution to that family as something socially worthy and deserving of decent wages. $^{71}$

To argue that women's wages were based on actual responsibility to others, however, did not demonstrate a direct relationship between

Aspiration and the "Rights that Belong to Us All," 74 J. AM. Hist. 1013 (1987).

68. Brief for Appellants, Adkins v. Children's Hosp., supra note 32, at 767.

69. Id. at 688-89, 877-78. Mary Anderson said the biggest job of the Women's Bureau was to overcome this myth, and it was mostly what its staff worked at. M. ANDERSON \& M. WinsLow, supra note 26, at 139-41. The breakthrough report-The Role of Women in Family Breadwinning-was applauded by The Nation as finally having "exploded" that myth. 117 THE NATION 129 (1923). Winifred Wandersee argues that during the twenties women worked to provide "extras" for their families, as both men and women were replacing the "value of work" with working for commodities. Rising expectations for families sent women to work, Wandersee points out, and although many women still worked out of need, in many instances the definition of need was changing. W. WANDERSEE, supra note 38 , at 71-73.

70. Brief for Appellants, supra note 32, at 762, 896-900.

71. Id. 
women's wages and their health and welfare, a connection which was necessary to prove the need for a police power exception to free contract. To provide such a link, Dewson couched wages in terms of a cycle of " "poor wages,' 'poor health,' 'poor wages" " which was a "descending spiral into the regions of destitution. ... Individual suffering," and the larger general "social loss" from low wages, which would bring "community decline," was "degrading to workers themselves." "2 Degradation was widespread, but it oppressed men as well as women. Dewson and Frankfurter needed to distinguish women from men to make an effective case for the women's minimum wage. Portraying women as strong, responsible workers and admitting that work itself was less harmful to them than low wages suggested a similarity between men and women. The right to a decent wage did not appear particularly gender bound. ${ }^{73}$

As industrial equality, the women's minimum wage was, to social feminists, a question of increased economic equality. Social feminists wanted wage laws for women so they would earn more money. There was a link between starvation and public health, but it was not gender specific. What was gender specific was women's devalued economic status. The brief for the minimum wage stressed poverty, which implicated the police power more than did other principles of industrial equality. But because it was also closer to an argument for universal wage laws for men as well as women, it interfered with the free contract ideology dominant in the twenties and the tandem philosophy of laissez-faire.

Thus, the major principle that women needed a legal floor on their wages because they earned less than men, and that economic disadvantage needed correction so that women could enjoy rights to equality and citizenship, was lost in the Adkins brief. Although the most important contribution of industrial equality was the merging of equality and difference, it had no real place within the police power. Furthermore, given Consumers' League legal counsel Felix Frankfurter's views on women's equality, it is not surprising that this aspect of industrial equality disappeared from the case. Largely defending a reversal of inequality, social feminists faced a police power rule that was not intended to promote equality, but to preserve public welfare. If women were entitled to such welfare because they supported others and were valuable to their communities, then men

72. Id. at 1023-24. Dewson and Frankfurter relied on the work of economists concerned with labor and wages, but not particularly with women. For examples of economists upon whom Frankfurter relied, see E.R.A. Seligman, Principles of Economics (1921); R. Ely, OUtlines of EcoNomics (1920).

73. In over one thousand pages of defense for the women's minimum wage, only 17 pages were devoted to any material that represented the effect of low wages on babies and therefore motherhood. This material, borrowed from the Children's Bureau, stressed the relationship between low wages and infant mortality, but it also came from an agency that advocated raising men's wages so women did not have to work. This was something of a departure from the way other social feminists-though in the same camp-were headed with industrial equality. Brief for Appellants, Adkins v. Children's Hosp., supra note 32 , at 1053-70. 
would also be entitled. From the Court's perspective, this extension made the women's minimum wage all the more threatening. Most significant for social feminism, however, was the process by which legal rules-in this case the police power-forced out more radical ideas so they would have no voice in the courtroom. ${ }^{74}$

\section{The Adkins Decision}

Justice Sutherland, one of Harding's recent conservative appointees, spoke for the Supreme Court's majority. He was quick to point out the difference between wages and other labor laws. To him, regulated wages meant a different kind of state involvement with the economy. But the Adkins case also represented a new view of women, and this was not lost on Sutherland. Politically distant from the liberal lawyers consulted by the Consumers' League, the very conservative Sutherland offered a new twist on the legal dilemma of equality and difference. Comparing this case to the hours test case, Muller, Sutherland noted that hours legislation had been upheld based on differences between men and women. ${ }^{75}$ And he was right. Looking at the world around him, he observed, however, the "ancient inequality of the sexes has continued with diminishing intensity."78 Why, since suffrage, inequality had almost reached the "vanishing point!"77 The result of this newly won equality for women, he reasoned, was that women had to be free to negotiate their own wages. ${ }^{78}$

Sutherland's denial of inequality, however, did not extend to overruling Muller. The result was curtailed hours without the benefit of increased wages. Sutherland saw no irony in declaring women free to work for any wage offered, but too inferior and dependent to choose hours of labor. The combination of low wages and restricted hours was worse for the woman who worked than no laws at all. ${ }^{79}$

Enlisting the theoretical equality of women to defeat the women's minimum wage, Sutherland found an effective means of turning social feminism against women. Sutherland's view of equality was that it meant sameness and identical treatment. Inequality had brought social feminists

74. On women's voices and legal structures in a more contemporary context, see White, supra note 61 .

75. Adkins v. Children's Hosp., 261 U.S. 525, 552-53 (1923).

76. Id.

77. Id.

78. Id. Sutherland relied on Lochner v. New York, 198 U.S. 45 (1905), in turning to free contract, even though many legal thinkers believed the case was no longer good law, and saw Sutherland's use of it as a return to nineteenth century social Darwinism. Interestingly, he glossed over Bunting v. Oregon, 243 U.S. 426 (1911), which would have provided a connection between labor laws and men, as well as voting citizens. But Frankfurter did not make much use of Bunting either.

79. See R.J. Lustig, Corporate Liberalism: The Origins of Modern american PolitiCAL THEORY, 1890-1920 (1982), on the power of the state to limit reform in capital's interests. Hours limitation arguably could have been in capital's interests because less worker fatigue may have meant increased worker production. Achieving that reform without increasing wages, however, constituted a limitation on reform in the interests of a class of employers. 
to recognize difference, but to Sutherland, equality and difference could never be reconciled. And by unevenly upholding hours regulation while striking down a floor on wages, he denied the possibility of self-sufficient womanhood, increasing chances of female poverty and dependency.

Oliver Wendell Holmes dissented. He saw no difference between wages and hours; if one could be regulated, he reasoned, why not regulate the other? He regarded his own opinion as "plain common sense," and intended it to "dethrone Liberty of Contract from the ascendancy in the Liberty business."B0 Nevertheless, Holmes could not resist commenting on women's equality. $\mathrm{He}$, unlike Sutherland, was certain suffrage did not create women's equality. "It will take more than the Nineteenth Amendment to convince me there are no differences between men and women, or that legislation cannot take those differences into account." ${ }^{\text {"81 }}$ Despite the fact that the politically liberal Holmes was more of a friend to women's labor laws than Sutherland, he too assumed it was inequality that mandated attention to difference. Equality, to his mind, was sameness. Much like Frankfurter, he used women's inequality to defend minimum wages for women. ${ }^{82}$

Judicial opinions drew on economic policy, free contract ideology, and the role of the state in minimum wage laws. All the justices seemed to be aware of the probability that the wage law would extend to men. ${ }^{88}$ The embodiment of twenties conservatism in Harding's Court was hostile to this path of policy development. The established economic-legal order of the twenties was clear on the issue of wages: tampering with them was inappropriate. Wage legislation appeared to jeopardize capitalism itself; conservatives refused to compromise free contract ideology for a policy they misconstrued as "bolshevism." Employers accepted hours regulation because they were able to rationalize hours limitation as part of industrial efficiency and, therefore, in their long-term profit interests. Wage legislation was perceived differently, however, because wages were directly linked to profits in the employer's mind. A state-imposed floor on women's wages looked like a profit cut, or at least interference with employer control. Profits were more sacred than motherhood. ${ }^{84}$

Economic policy, however dominant, was not the only significant aspect of Adkins. All the Justices and lawyers involved somehow grappled with women's equality and difference. Certainly, Sutherland used women's

80. 1 Holmes-Laski Letters 495 (M. Howe ed. 1953).

81. Adkins v. Children's Hosp., 261 U.S. 525, 570 (Holmes, J., dissenting).

82. Id.

83. Sutherland spent a good deal of time discussing men's hours laws, which only would have been necessary to block wages for men, id. at 548-52 (majority opinion); and although Taft insisted he was avoiding an opinion on men's laws, this was nevertheless on his mind. Id. at 566 (Taft, J., dissenting).

84. It would take a great deal of political pressure to get this Court finally to yield to a minimum wage for women in 1937. West Coast Hotel Co. v. Parrish, 300 U.S. 379 (1937). That pressure was not present in 1923. 
equality to rationalize his opposition to labor laws, but Holmes used women's inequality to defend the minimum wage. A contradiction had developed between equality and labor reform for women. Were women entitled to these reforms because they were entitled to equality, as social feminists argued, or to inequality, as Holmes argued? Did constitutional equality mean "identity of treatment," as social feminists had feared, and as Sutherland articulated? Social feminists had been trying to suggest that women's equality could be defined legally in women's difference, without loss and without contradiction. The contradiction imposed by legal ideology distorted feminist theory.

\section{Conclusion: Social Feminism and Legal Discourse}

In the period between 1900 and 1923 the status of women had changed considerably. Observers had come to understand that women were marrying at a later age and were working to support themselves. Married women worked to support children, often but not always with the help of husbands. Young women at home often worked to support their parents. And women had moved into the public sphere in unprecedented numbers; they seemed to be there to stay. Social feminists had moved into leadership ranks of their national and local organizations, as well as into some government posts. An organized women's movement had won the Nineteenth Amendment.

Social feminism had changed too. Those who supported women's labor laws viewed women as independent and important, a significant change from the older view of women as weak and dependent. The earlier women's labor law case, Muller, had presented just that view. But the woman of Adkins was clearly not the woman of Muller. ${ }^{85}$

Industrial equality was an idea that tried to merge women's equality with women's different experience to account for women's disadvantages so as to alleviate them. It was a practical bridge between the law's rigid definition of equality-as-sameness and social feminists' idea of equalitythrough-difference. It also served as an ideological bridge between the separate spheres of men and women and women's political integration, and therefore, reflected social feminists' own social reality in the 1920's.

Social feminists believed these were all reasons to expect the Supreme Court to uphold women's minimum wage laws. But the Court turned these gains against women. Denying the validity of women's minimum wage laws, the Court used equality rhetoric, and especially suffrage, against feminism, and hid behind a mask of equality for women, while defeating what most of the Justices saw as a bid for the "redistributive"

85. Social feminists reiterated their proud accomplishments at their conferences, in their pamphlets and in their correspondence. Nonetheless, none of them ever explicitly noticed changes since Muller, nor did they actively repudiate earlier arguments. 
state. Suffrage, and the equal citizenship it implied, had empowered social feminists and had provided the groundwork for the idea of "industrial equality." But as Florence Kelley observed, Sutherland essentially argued that since suffrage, women had won the equal right to starve. ${ }^{86}$ Ironically, social feminists had thought introduction of the ERA might create this problem; nobody dreamed suffrage alone had this legal capacity.

While victories in the suffrage movement and in women's labor law cases had encouraged women to act and had instilled in them a deep faith in legal process as an agent of social change, law also revealed the capacity to hold back the social feminist agenda by turning equality rhetoric against women. This was especially true when social feminist demands moved into the sphere of direct economic consideration. Even though social feminists advocated the women's minimum wage in defense of industrial equality, their lawyers and the judges they encountered in Adkins never quite comprehended this concept. To them, separate laws for women were a matter of inequality. The only legal friends these social feminists found were those who defended women's labor laws because they favored women's inequality.

During the Adkins years, social feminists championed the women's minimum wage as a feminist cause. And women's labor laws were symbolic of social feminists' own women's political culture. In 1923 these social feminists were ambivalent about entering the male spheres of power, and the industrial equality theory they used to defend minimum wage laws for women reflected that ambivalence. When labor laws for all workers were validated by the Court in 1941, male reformers declared that victory would not have been possible without all the hard work of women in previous years. ${ }^{87}$ Women workers and social feminists were a "wedge" that had opened the way for larger reform. Although women rejoiced at this victory, by then they had given up their women's political culture, and women's labor laws had ceased to have any meaning for feminism.

When the notion of industrial equality failed in Adkins, social feminists became afraid and demoralized. They believed in legal victory, had grown dependent on it to legitimate themselves, and they began to want a place inside the power structure, rather than in a separate women's culture. They returned to old ideas that worked. The focus of their legal arguments post-Adkins, especially in the thirties, drew upon sacred motherhood, preservation of the race, and women as reproducers who needed protection. They had sacrificed a much more promising-and potentially radical-ideology at the altar of legal acceptability.

86. Speech of Florence Kelley (1925) (Reel 100, in National Consumers' League Collection, at Manuscripts Division, Library of Congress).

87. Address of Hon. Robert F. Wagner, Women in Industry, at the Public Affairs Dinner of the Institute of Women's Professional Relations (Mar. 28, 1935) (Reel 31, in National Consumers' League Collection, at Manuscripts Division, Library of Congress). 
Social feminists were limited by the need to put their ideal of industrial equality into legal discourse. In transposing social feminist language into legal rhetoric, Molly Dewson and Florence Kelley faced the legal system's incapacity for recognizing gender differences. The standard for personhood in the law, social feminists were aware, was a male standard. To gain equality in such a system, it was necessary to be the same as that male model of personhood. Social feminists saw themselves as confronting the male standard in law by emphasizing women's differences. They tried to win equality in difference, but they were up against the legal contradictions between equality and difference. The notion of equality and difference as binary opposites emerged out of the legal test of the women's minimum wage, but it was imposed by legal ideology on social feminist ideals. 